ANDRÁS LAKATOS, M.Sc. ${ }^{1}$

(Corresponding author)

E-mail: lakatos.andras@mail.bme.hu

PÉTER MÁNDOKI, Ph.D. ${ }^{1}$

E-mail: mandoki.peter@mail.bme.hu

${ }^{1}$ Department of Transport Technology and Economics

Budapest University of Technology and Economics

Müegyetem rakpart 3, H-1111 Budapest, Hungary
Traffic Management Original Scientific Paper

Submitted: 3 July 2019

Accepted: 19 Feb. 2020

\title{
ANALYTICAL, LOGIT MODEL-BASED EXAMINATION OF THE HUNGARIAN REGIONAL PARALLEL PUBLIC TRANSPORT SYSTEM
}

\begin{abstract}
The ongoing competition between bus and railway systems in the Hungarian regional passenger transport is a current problem, because these subsectors need to complement each other, instead of being in the government-funded competition. Long-term sustainability and efficiency in passenger transport require a balanced transport policy. The parallel bus and railway links, which are present in all regions of Hungary can result in competition. This research explores the solutions to this issue for long-term environmental and economic sustainability optimization. An objective index and interventions developed in previous studies have been applied here. This investigation is to validate the objective index and the interventions by using the Logit model.
\end{abstract}

\section{KEY WORDS}

parallel public transport system; logit model; mode choice; quality index; weighted coefficient;

\section{INTRODUCTION}

Public transport plays a significant role in the people's lives in Hungary, also affecting the national economy. Therefore, its development is essential for long-term environmental and economic sustainability [1]. Even though there is constant innovation, thanks to both governmental and EU subsidies, the necessary macroscopic traffic organizational tasks remain marginalized.

From the government point of view, the long-term solution would be a market-based, non-state-subsidized passenger transport service. However, the decree regulation (EC) No. 1370/2007 of the European Parliament states that "[...] currently multiple countrywide passenger transport services meet the needs of general economic interest, therefore cannot be operated on a commercial basis".
The modal split between transport subsectors was researched in Hungary by Farkas, Hagymási and Nagy [2], as well as Ács [3], whose investigations concern the comparative analysis of subsectors. Internationally, Abramovic, Zitricky and Mesko [4], Abramović [5], Droździel et al. [6], Gašparík, Abramović and Zitrický [7], Gasparik, Mesko and Zahumenska [8], Zitrický, Černá and Abramović [9], Kuang et al. [10], Llano et al. [11], van der Weijde et al. [12] investigated this topic. Albert and Tóth [13] discussed this topic in a more detailed manner, arriving at an index number which gives results from the operator's aspect. Zhu et al. [14] studied the problem from the management's point of view.

To fill the gap of international research, in previous studies of Lakatos and Mándoki [15], [16] a new quality index number $(M)$ was calculated (Equation 1) - regarding the parallel service links in Figure 1 based on some of the critical factors which include: the number of inhabitants to be served, public transport availability, and efficiency in time of travel for vehicles and passengers.

$M=\sum_{j=1}^{n}\left(\frac{1}{n_{\text {dayi } i, b}} \cdot t_{\text {travel } i, j, b} \cdot p_{j}-\frac{1}{n_{\text {day } i, j, v}} \cdot t_{\text {travel }}, j, v \cdot p_{j}\right)$

where:

$i \quad-$ settlement of departure;

$j \quad-$ serial number of destination settlement;

$b$ or $v$-examined transport mode (bus (b) or train (v));

$n_{\text {day } i_{i, b},}$-daily supply in two directions in the case of bus service between each settlement served by the examined links [departures/ day]; 


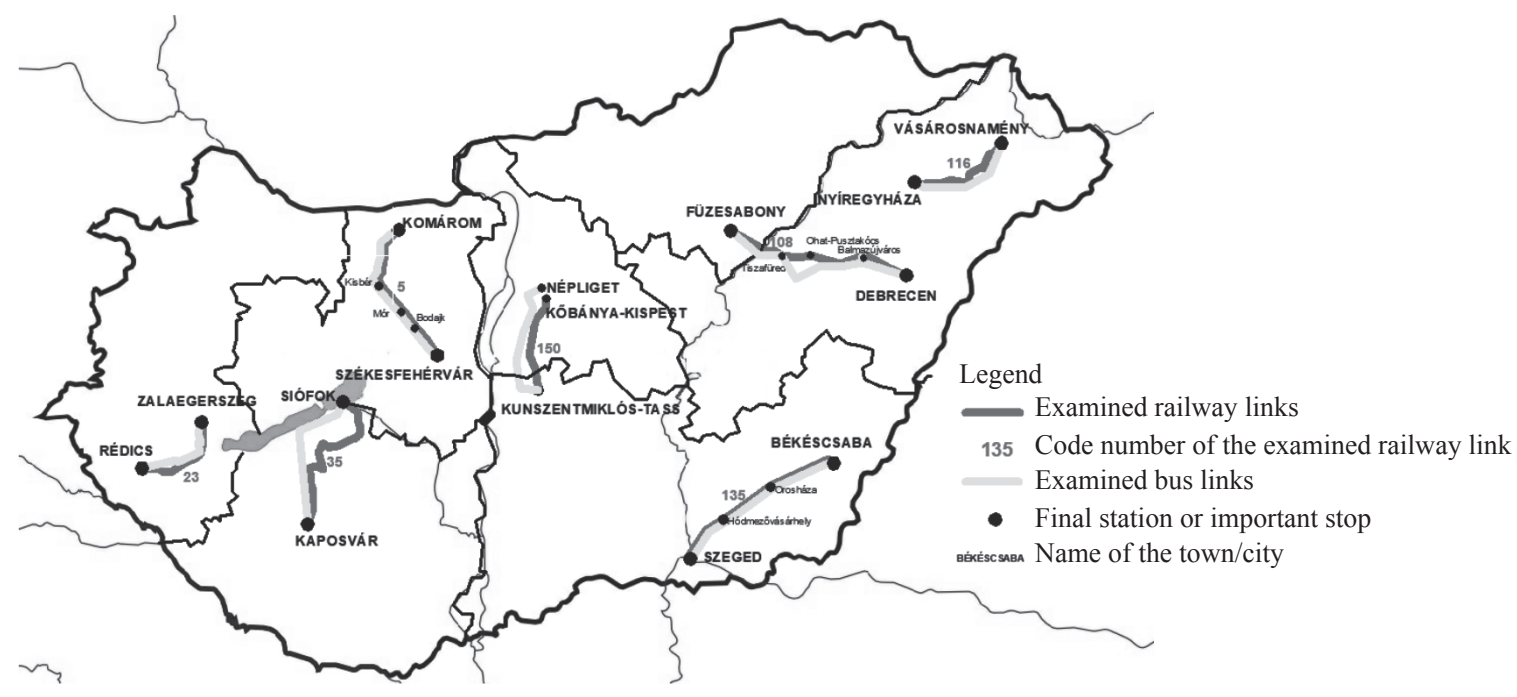

Figure 1 - Examined parallel (regional train and bus) links

$n_{\text {dayi, }, v}$-daily supply in two directions in the case of train service between each settlement served by the examined links [departures/ day];

$t_{\text {travel } l_{i, b}, \text { }}$-travel time using bus service between each settlement covered by the examined links [min];

$t_{\text {travel } i, j, v}$-travel time using train service between each settlement covered by the examined links [min];

$p_{j} \quad$-factor of the number of inhabitants in settlements covered by the examined links [16].

The data on travel time and daily supply data were given by the public transport companies (Volánbusz Zrt., MÁV-Start Zrt.), and the official number of inhabitants was provided by the Hungarian Central Statistical Office (KSH).

Regarding the examined parallel links, the values of the quality index number $M$ and the suggested interventions are presented in Table 1 and Figure 2 [16].

Table 1 - Value of the quality index $M$ for each examined parallel link [16]

\begin{tabular}{||l|c||}
\hline \multicolumn{1}{|c|}{ Name of the parallel line } & $M$ \\
\hline \hline Kaposvár - Siófok & -19.29 \\
\hline Székesfehérvár - Komárom & -13.71 \\
\hline Nyíregyháza - Vásárosneamény & -1.68 \\
\hline Zalaegerszeg - Rédics & -5.0 \\
\hline Szeged - Békéscsaba & -0.29 \\
\hline Budapest - Kunszentmiklós & 2.03 \\
\hline Debrecen - Füzesabony & 4.97 \\
\hline
\end{tabular}

The purpose of this paper is to analytically validate the borders of intervals in the quality index number function (Figure 2). For the travel links depicted in Figure 1, the weighted coefficients of mode choice depending on the values of quality index number are to be determined, based on logistic regression (logit model) - as a mathematical tool - and on the number of passengers counted on the chosen parallel links. The functions of different weighted factors can be determined using the quality index number $M$. An analysis of these functions and their extreme values on the borders of the intervals in Figure 2 are to be corrected.

The research framework is shown in Figure 3.

\section{METHODOLOGY}

The spatial and temporal distribution of trips is determined by the quality of the existing transport modes. The mode choice can be described by a probability model based on the spatial distribution of trips [17].

Two explanations of the Logit model (logistic regression) exist $[18,19]$. The simpler and probably more popular formulation is a probability Equation 2:

$\operatorname{logit}(y=1)=\beta \cdot x$

where $y$ is a discrete dependent variable $(y=1$ is "success" $y=0$ is "failure"), the logit function is the logarithm of the event chance in an argument, in turn, $\beta \cdot x$ is a linear combination of the coefficient and the explanatory variable. The $\beta$ coefficients are the parameters of logistic regression. Though on the right side there is no failure term, the stochastic connection between the observed output and the 


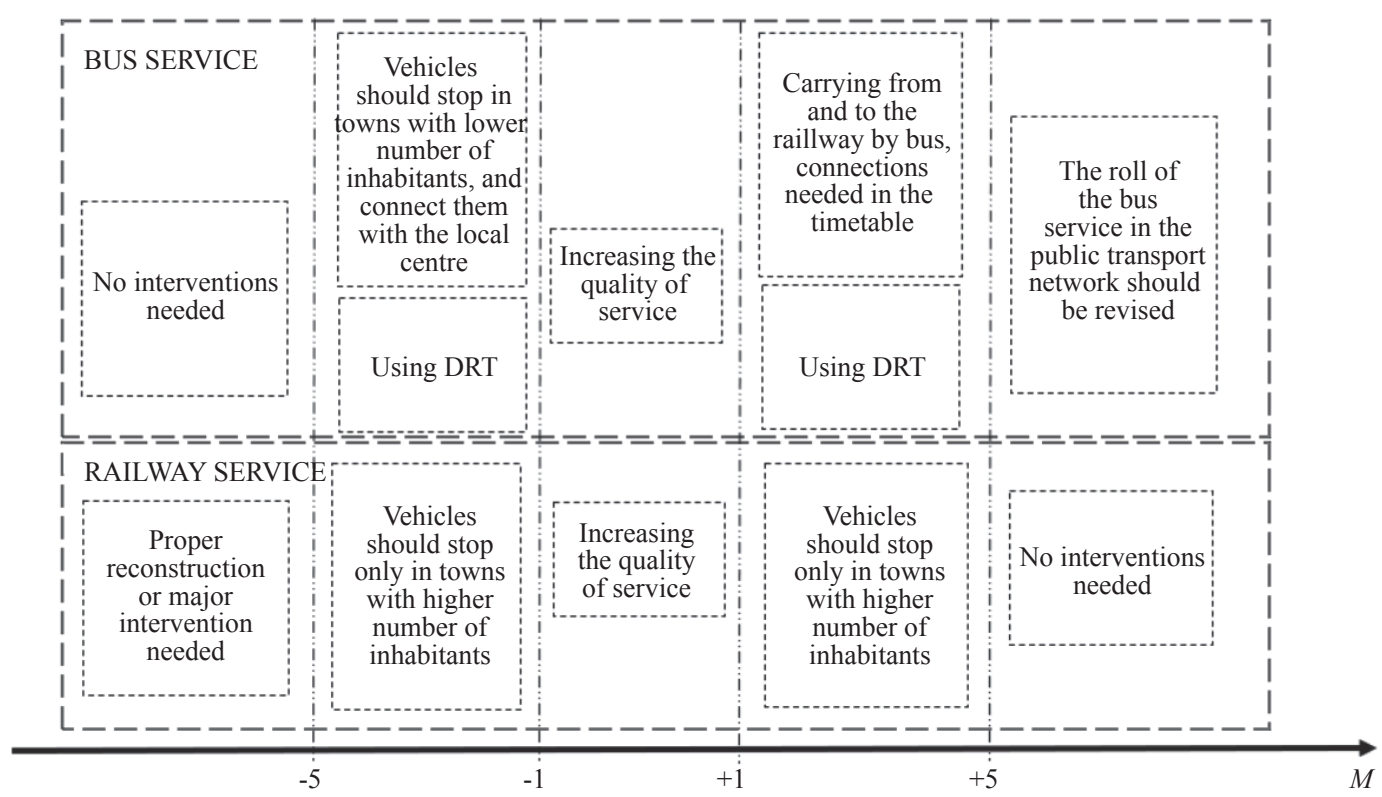

Figure 2 - Suggested interventions depending on the values of the quality index number [16] Note: DRT means Demand Responsive Transport.

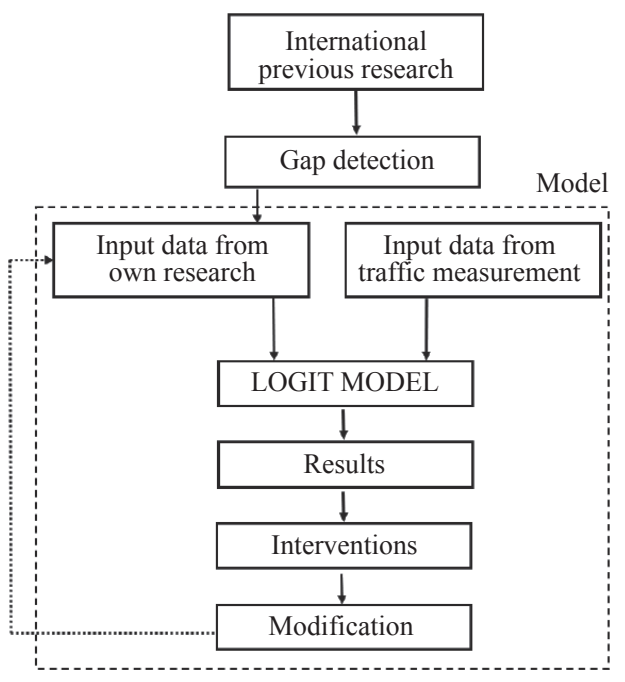

Figure 3 - Research framework

explanatory variables are referred to by the left side, where the logarithm of a chance of occurrence appears, not the observed output.

Probability of success $(P)$ can be defined by the following method:

$$
\begin{aligned}
& P(y=1)=P(\alpha x+<\sigma \varepsilon>0)= \\
& =P\left(\varepsilon>-\frac{\alpha x}{\sigma}\right)=1-F\left(-\frac{\alpha x}{\sigma}\right)
\end{aligned}
$$

where:

$\alpha x$-linear combination of describing the variables and coefficients;

$\varepsilon-\operatorname{logistic}$ function;

$\sigma$-deviation.

The logistic distribution function is symmetrical, so the probability of success is:

$$
P(y=1)=F\left(\frac{\alpha x}{\sigma}\right)
$$

As Functions 2 and 3 define the same probability, the connection between the direct probability model $\beta$ coefficients and the latent coefficient-based linear regression model $\alpha$ coefficient describes Function 5 [20]:

$\beta=\frac{\alpha}{\sigma}$

In order for the attributions of each transport mode (in this case bus and railway) to be evaluated based on their weights, a utility function has to be determined for all of the choices, based on the linear combination of weight numbers attributes $\left(g_{m}\right)$. The generic form of this utility function is given by:

$U\left(x_{1}, x_{2}, \ldots, x_{n}\right)$

In this case, two transport modes are examined (bus and railway), so the utility functions are, respectively:

$U_{b}=x_{11} \cdot g_{1}+x_{12} \cdot g_{2}+\ldots+x_{1 m} \cdot g_{m}$

$U_{v}=x_{21} \cdot g_{1}+x_{22} \cdot g_{2}+\ldots+x_{2 m} \cdot g_{m}$

where:

$x_{n m}$-evaluable attribute " $m$ " in choice " $n$ ";

$g_{m}$-attribute weight number;

$U_{b}$-utility function, which describes the bus transport system;

$U_{v}$-utility function, which describes the railway transport system. 
When choosing a way of transport, the most frequent attributes are cost and time, which were calculated in a previous study [16] for the examined seven regional parallel links. These cost and time values are based on travels from city centres to city centres. Transforming Equations 7 and 8, the following utility functions can be defined:

$U_{b}=T_{b i, j} \cdot w_{t, b}+K_{b i, j} \cdot w_{c, b}$
$U_{v}=T_{v i, j} \cdot w_{t, v}+K_{v i, j} \cdot w_{c, v}$

where:

$T_{b i, j}$-value of travel time between settlements $i$ and $j$ using the bus transport system;

$K_{b i, j}$-value of travel cost between settlements $i$ and $j$ using the bus transport system;

$w_{t, b}$-weighted coefficient of travel time using the bus transport system;

$w_{c, b}$-weighted coefficient of travel cost using the bus transport system;

$T_{v i, j}$-value of travel time between settlements $i$ and $j$ using the railway system;

$K_{v i, j}$-value of travel cost between settlements $i$ and $j$ using the railway system;

$w_{t, v}$-weighted coefficient of travel time using the railway system;

$w_{c, v}$ - weighted coefficient of travel cost using the railway system.

The utility function was calibrated based on literature data by Martínez, Aguila and Hurtubia [22], Tánczos and Török [23], Kosztyó and Török [24].

In each case, the probability of bus $\left(P_{b}\right)$ and train $\left(P_{v}\right)$ can be defined by the function values of $U_{b}$ and $U_{v}$, respectively:

$P_{b}=f\left(U_{b}, U_{v}\right)$

$P_{v}=f\left(U_{b}, U_{v}\right)$

Using a logit model to the binary case - mentioned above:

$$
\begin{aligned}
& P_{n=1}=\frac{e^{U_{n}=1}}{\sum_{n=1}^{2} e^{U_{n}}}=\frac{e^{U_{1}}}{e^{U_{1}}-e^{U_{2}}} \\
& P_{b}=\frac{e^{U_{b}}}{e^{U_{v}}+e^{U_{b}}}= \\
& =\frac{e^{T b_{i, j} \cdot w_{t, b}+K b i_{j} \cdot w_{c, b}}}{e^{T v_{i, j} \cdot w_{t, v}+K v_{i, j} \cdot w_{c, v}}+e^{T b i, j} \cdot w_{t, b}+K b i_{j} \cdot w_{c, b}} \\
& P_{v}=\frac{e^{T_{v i, j} \cdot w_{t, v}+K_{v i, j} \cdot w_{c, v}}}{e^{T_{v i, j} \cdot w_{t, v}+K_{v i, j} \cdot w_{c, v}}+e^{T_{b i, j} \cdot w_{t, b}+K_{b i, j} \cdot w_{c, b}}}
\end{aligned}
$$

where: $0 \leq P_{n} \leq 1$ and $P_{b}+P_{v}=1$.
In the utility functions, the values of travel cost and travel times are known. The number of passengers was taken from the official national traffic measurement organized by KTI Institute for Transport Sciences in 2016 [21]. The observation-based probability values of $\widehat{P_{b i, j}}$ and $\widehat{P_{v i, j}}$ can be calculated:

$$
\begin{gathered}
\widehat{P_{b i, j}}=\frac{N_{b i, j}}{N_{\ddot{o} i, j}} \\
\widehat{P_{v i, j}}=\frac{N_{v i, j}}{N_{\ddot{o} i, j}}
\end{gathered}
$$

where:

$N_{b i, j}$-number of passengers between settlements $i$ and $j$ based on national traffic measurement in the bus transport system;

$N_{v i, j}$-number of passengers between settlements $i$ and $j$ based on national traffic measurement in the railway system;

$N_{\ddot{o} i, j}=N_{b i, j}+N_{v i, j}$-number of all passengers between settlements $i$ and $j$ based on national traffic measurement

The values of weighted coefficients in the utility function are defined as the minimum of sum-failures of probabilities in logit model $\left(P_{b}, P_{v}\right)$ and the probabilities based on the traffic measurement $\left(\widehat{P_{b i}, j}, \widehat{P_{v i, j}}\right)$. The minimum value $(\mathrm{Min}$.) can be calculated with residual sum of squares:

$\sum_{i, j}\left(\widehat{P_{b i, j}}-P_{b}\right)^{2} \rightarrow$ Min.

$\sum_{i, j}\left(\widehat{P_{v i, j}}-P_{v}\right)^{2} \rightarrow$ Min.

More particularly:

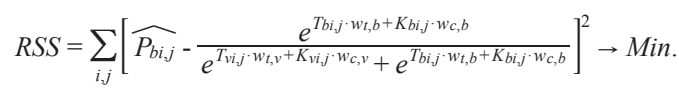

$R S S=\sum_{i, j}\left[\widehat{P_{v i, j}}-\frac{e^{T_{v i, j} \cdot w_{t, v}+K k_{i j} \cdot w_{c, v}}}{e^{T_{v i, j} \cdot w_{t, v}+K_{v i, j} \cdot w_{c, v}}+e^{T_{b i, j} \cdot w_{t, b}+K b_{i, j} \cdot w_{c, b}}}\right]^{2} \rightarrow$ Min.

To define the values of weighted coefficients in each relation more exactly, the calculations were made with MS Solver.

For each parallel link mentioned in Figure 1, the values of travel time and travel cost-weighted coefficients were calculated with Equations 20 and 21.

\section{RESULTS}

The calculated values of the weighted coefficients can be assigned to the values of quality index $(M)$ of each parallel link (Table 2).

\section{ANALYSIS AND DISCUSSION}

It is important to emphasize that the suggested interventions [16] were set for reaching the highest travel time-weighted coefficients by a previous 
Lakatos A, Mándoki P. Analytical, Logit Model-based Examination of the Hungarian Regional Parallel Public Transport System

Table 2 - Values of weighted coefficients in the function of values of the M quality index

\begin{tabular}{||c|c||c|c|c|c|c|c|c||}
\hline \hline \multirow{3}{*}{ Railway } & $M[-]$ & -19.29 & -13.71 & -5 & -1.68 & -0.29 & 2.03 & 4.97 \\
\cline { 2 - 11 } & $w_{t}[-]$ & 0.486 & 0.442 & 0.426 & 0.200 & 0.521 & 0.300 & 0.539 \\
\cline { 2 - 10 } & $w_{c}[-]$ & 0.514 & 0.558 & 0.574 & 0.800 & 0.479 & 0.700 & 0.461 \\
\hline \multirow{2}{*}{ Bus } & $w_{t}[-]$ & 0.514 & 0.558 & 0.574 & 0.800 & 0.479 & 0.700 & 0.461 \\
\cline { 2 - 10 } & $w_{c}[-]$ & 0.486 & 0.442 & 0.426 & 0.200 & 0.521 & 0.300 & 0.539 \\
\hline
\end{tabular}

Note: $M$; wt; wc were defined in Eq. (9) and (10) and in section Introduction.

study [25]. Namely, when travelling over relatively short distances (below 100 kilometres), most of the respondents (approximately 80\%) choose travel time as the most important factor influencing their choice.

Based on the present results, Figures 4 and 5 symbolize the travel cost and travel time values depending on the values of the quality index number $M$. As per functions in Figures 4 and 5, there are six different intervals (hereinafter referred to as No. 1, No. 2 , etc.).

1) $M<-5$

2) $-5<M<-2$

3) $-2<M<2$

4) $2<M<5$

5) $5<M<10$

6) $M>10.62 \sim 11$

If $M<-5, w_{t}$ is constant as shown in Figure 4 . Though, near the -15 value of $M$, the distance between the links decreases, but based on the degree of variance, both of the functions can be constant. It must be noted that $55 \%$ of passengers [21] choose the bus transport system, which guarantees better travel time values. For those who choose the train service, the travel cost affects the mode choice (Figure 5). Results of traffic measurement prove the same, because in interval No. 1 a significant (approximately 60-70 times) difference can be experienced in favour of the bus transport system in the number of passengers. The constant nature of the function in Figure 4 validates the interventions (Figure 2) because bus links can serve - with preferential travel time values - the commuting traffic. In the railway system a more significant investment (e.g. introducing electric railway links, re-planning track routes, increasing the speed, etc.) can be the solution. The high costs of such changes must be considered. Railway links that belong to Interval No. 1 (Kaposvár - Siófok, Székesfehérvár - Komárom, Zalaegerszeg - Rédics) have the same characteristics; they serve rural areas with settlements having 1001,000 inhabitants. The train stations are near the settlement's border, and the supply is symbolical, too. On the opposite side, the bus service guarantees preferential, better values of travel time and bus stops are in the centres of the settlements.

In Interval No. 2 the cost function rises steeply, which changes the sign at quality index value -1.68 . Because of this, the original border of intervals based on previous research [16] - has to be refined from value -1 to -2 . In the modified interval the effect of wt on mode choice permanently increases for those who choose the bus service, while the train is used decisively for its cost. The maximum difference between wt and wc is significant, ca. 0.6. Therefore, railway transport can be competitive only regarding

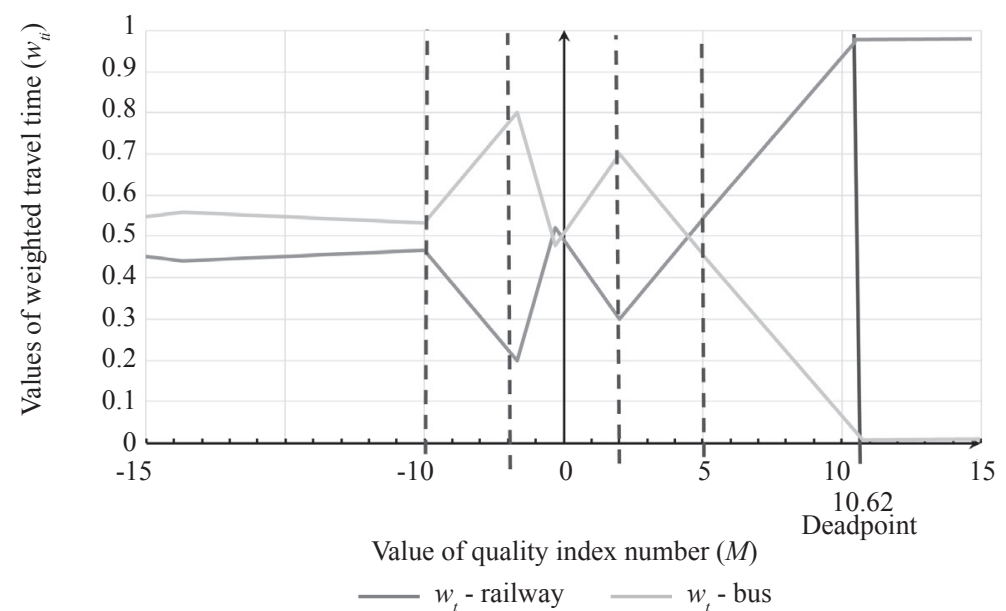

Figure 4 - Effect of travel time values on mode choice according to the quality index $M$ in the case of parallel service 


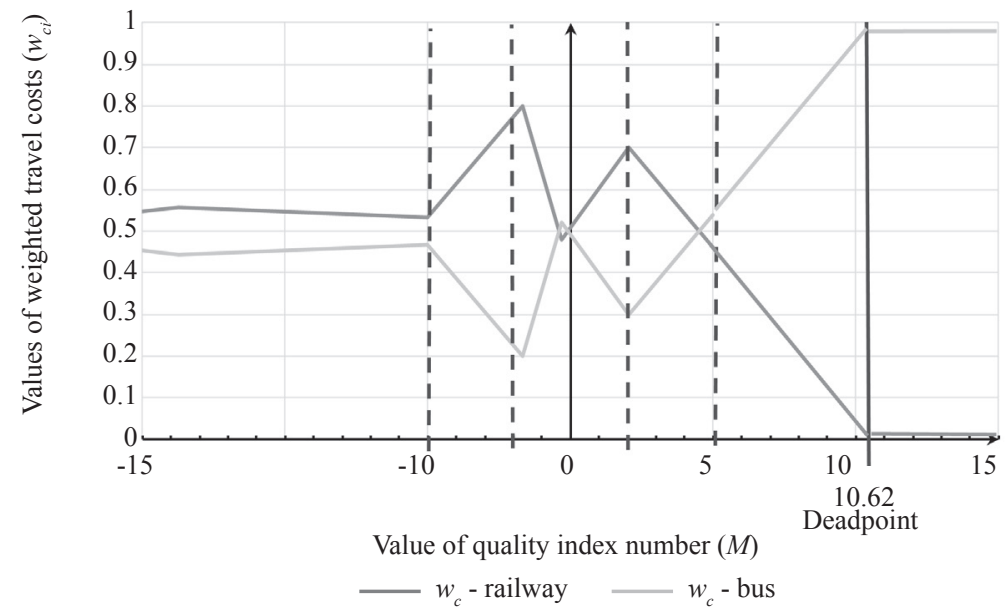

Figure 5 - Effect of travel cost values on mode choice according to the quality index $M$ in the case of parallel service

the travel cost. The train stops should be optimized along the railway link to decrease the travel times. This change can result in increasing the quality index value, and thus increase the competitiveness of railway transport. Unused railway stops should be served by demand-responsive bus transport. The effect of stop optimization on competitiveness has already been used by the Finnish railway and in Hungary by the MÁV-HÉV company [26, 27].

Interval No. 3 should be divided into two parts based on Figures 4 and 5 :

a) section between values -2 and 0 ;

b) section between values 0 and 2 .

In section a) the rise of $w_{t}$ line for the bus service increases (ca. 51 degrees) and takes a negative value, while for the railway transport the opposite of this can be noticed, which results in a quick change. Close to the zero value of the quality index $M$, the weighted coefficients of bus and railway are nearly equal; therefore, the travel time and the travel cost are equally crucial for the passengers, which results in competition.

The interval section b) shows a surprising result; namely, the bus system can efficiently serve the travel time, which weighted significantly for passengers in their mode choice. At the same time, it is essential to mention that the difference of the weighted travel time values is far lower (ca. 0.4) than the difference value in interval No. 2 , and the rises of the functions are again ca. 40 degrees.

Considering the minor differences between sections a) and b), the suggested intervention should be the stop optimization of the railway link. If the approximation of the value of the weighted coefficients is beneficial, then the train stop optimization should be done on the train link. For example, the Szeged-Békéscsaba railway link and the corresponding parallel bus links belong to this category. They cover the areas with a higher population, guarantee the same supply (except between Szeged and Hódmezővásárhely). Furthermore, train and bus stops are located next to each other and near the city centre. This would decrease the travel time, and increase the service level of both transport modes by distributing the travel demand in time and space between the two public transport systems (e.g. parallel service only during rush hour, feeder bus links with railway-coordinated timetables in off-peak hours). Introducing business politically reduced fares (e.g. combined pass etc.) should also be considered. Parallel railway and bus links with the value of $M$ between -2 and 2 cover the densely populated areas and connect high-populated cities by collecting people from different points of the settlements. Accordingly, both transport modes should operate, and their service level can be developed with some extra services (e.g. on-board Wi-Fi, modern vehicles, etc.) or with the more exact recognition of demand.

In Interval No. 4 the guaranteed weight number of travel time permanently shows a decreasing trend, while the railway function is increasing. It means that the services approach race condition, which is symbolized by the intersection of functions near the quality index value 5 . To increase the travel time-based competitiveness of railway transport, stop optimization, and feeder bus system are needed. Unused railway stops should be served by demand-responsive bus transport.

In the case of No. 5, the bus systems function decreases until the endpoint $(10.62 \sim 11)$, where it takes a constant value (0.01). Meanwhile, the railway transport function permanently increases until 


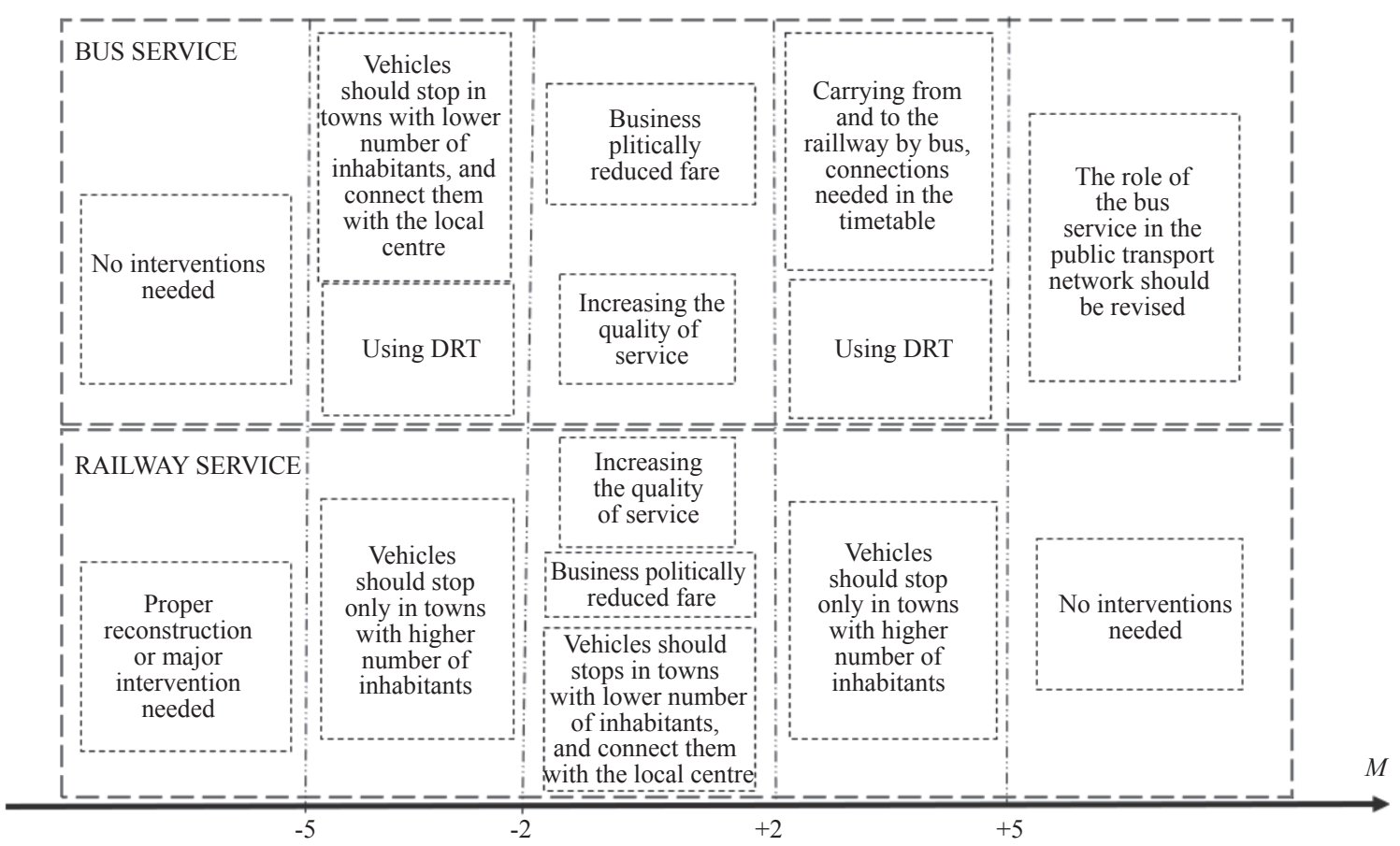

Figure 6-Suggested interventions depending on the refined value of the quality index number

the endpoint, where it reaches the maximum value (0.99) and takes constant characteristics (Interval No. 6). So it is essential to mention that if the value of quality index $M$ is above the endpoint, it is not a rational instance of parallel service, because worthwhile benefits of mode choice cannot be reached in travel time or travel cost.

In Interval No. 5 railway transport is chosen by the passengers because of shorter travel times, while those who choose the bus transport system, mostly weight travel costs. Though - similarly to Interval No. 1 - there are enormous differences between the passenger numbers of the two transport modes, here in favour of the railway transport. Based on this, there is no suggested intervention for railway transport, while the role of bus links in the transport system should be reconsidered.

The revised suggested interventions depending on the refined value of the quality index number are given in Figure 6.

In the course of previous research [16], parallel bus and railway links between Debrecen and Füzesabony were optimized based on the suggested interventions above and a Finnish example. Accordingly, the $M$ value advanced from 4.97 to 7.80 . Applying the new value to Figures 4 and 5, it can be stated that the competition between the parallel links ceased, the function of the railway reached the maximum point on travel time values as a weighted coefficient, while passengers choose bus because of the travel costs .

As Figure 7 suggests, the interventions would cause advancement in the number of passengers using railways, because if the value of quality index $M$ is above zero, the number of transported passengers increases in the railway system, while below 0 , the passengers tend to use buses.

It is important to mention that the commuter passengers (travelling a distance below 100 kilometres) choose the transport mode which guarantees the shortest travel time, as proved by [15].

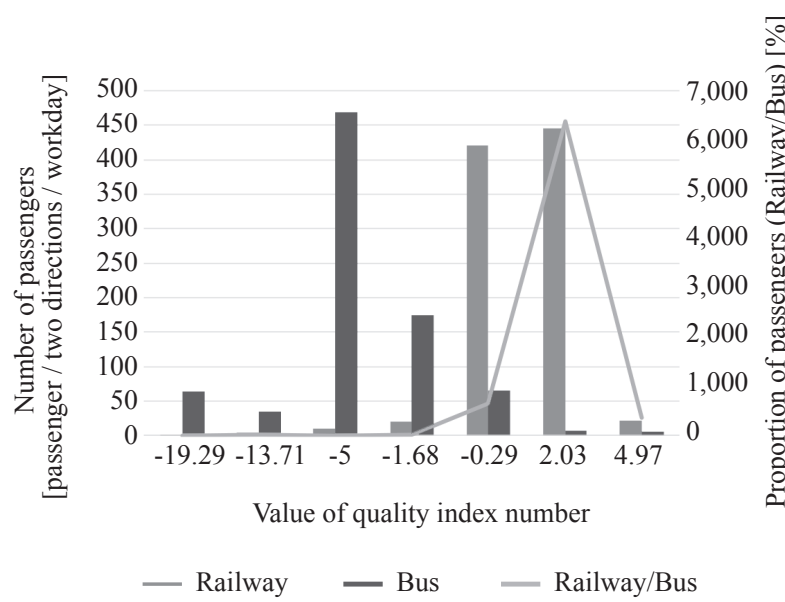

Figure 7 - Number of passengers in each transport mode depending on the quality index number 


\section{CONCLUSION}

This study aimed to support analytically the use of the objective index $M$ and interventions in the traffic system. For the verification, the values of travel time and travel costs, furthermore the number of passengers in each parallel bus and railway link - covering all the regions of Hungary - were evaluated with a logit model.

For both transport modes, the weighted travel time and travel cost values were calculated and assigned to the quality index number $M$. Consequently, the functions of weighted coefficients are reflected by the quality index intervals, which show the characteristics of competition between bus and railway systems.

If the value of quality index number is below -5 , then the functions of the weighted coefficients are constant, and the bus system is chosen by most of the passengers because it guarantees shorter travel times. The high values of the function reflect this statement. In this case, the competitiveness of railway transport cannot be increased by only transport organization tools.

The functions of the weighted coefficients have ca. 45-degree slope between the value of quality index -5 and -1 . In this interval the railway competitiveness can be increased by stop optimization. In interval -1 and +1 the lines change signs and their slopes approximate to competition point, which can be reached when the quality index number equals 0 . As the slope of the lines changes the sign near the quality index number -2 , the interval border determined by a previous study [16] has to be modified from -1 to -2 .

There is a significant change near the quality index value +2 . The function of the weighted coefficients according to the bus system has a slope with a negative value, while the function of the railway service shows the opposite trend, but the difference between the two functions is insignificant. Based on the statements above, the value of the internal border should be modified from +1 to +2 .

Above the value of quality index number +5 , the competition between the two transport modes disappears, the difference between the two functions permanently grows until value +10.62 (endpoint). From the endpoint, the functions reach the maximum and the minimum values (0.99 and 0.01). Above the mentioned point, it is not rational to aim at a higher quality index value, because functions have constant characteristics. Accordingly, the weight of the mode choice parameters is invariable.
A previous study [15] proved that for the passengers (ca. 80\%) the travel time is the most important in their mode choice. Accordingly, to reach the highest value on the weighted coefficient lines in each quality index interval - considering the transport political aspects - the suggested interventions are relevant. Hungarian parallelism in regional public transport can be optimized by the created methodology and suggested interventions. This methodology can be used generally in every transport mode competition or to influence the public transport mode choice.

\section{ACKNOWLEDGEMENT}

Authors are grateful for the support of Péter MIKSZTAI, researcher of KTI Institute for Transport Sciences by supplying traffic measurement data within the confines of OCF-2016 project.

LAKATOS ANDRÁS, M. Sc. ${ }^{1}$

E-mail: lakatos.andras@mail.bme.hu

MÁNDOKI PÉTER, Ph.D. ${ }^{1}$

E-mail: mandoki.peter@mail.bme.hu

${ }^{1}$ Közlekedésüzemi és Közlekedésgazdasági Tanszék Budapesti Müszaki és Gazdaságtudományi Egyetem Múegyetem rakpart 3, H-1111 Budapest, Magyarország

\section{A MAGYARORSZÁGI REGIONÁLIS PÁRHUZAMOS KÖZÖSSÉGI KÖZLEKEDÉSI RENDSZER ANALITIKUS, LOGIT-MODELL ALAPÚ VIZSGÁLATA}

\section{ABSZTRAKT}

$A z$ autóbusz- és vasúti közösségi közlekedési rendszerek között fennálló verseny a magyar regionális személyszállitásban aktuális probléma, mivel ezeknek az alágazatoknak ki kell egésziteniük egymást az államilag finanszirozott verseny helyett. A személyszállitás hosszú távú fenntarthatósága és hatékonysága kiegyensúlyozott közlekedéspolitikai környezetet igényel. A párhuzamos busz- és vasútvonalak, amelyek Magyarország minden régiójában megtalálhatók, versenyhelyzetet eredményezhetnek. Ez a kutatás a fenti probléma megoldásait vizsgálja a hosszú távú környezeti és gazdasági fenntarthatóság érdekében, amelynek alapját egy korábbi tanulmányban kidolgozott objektiv mutatószámok és azokhoz társitott beavatkozások képezik. Ezen vizsgálat célja az objektiv index és a beavatkozások validálása a Logit-modell segitségével.

\section{KULCSSZAVAK}

módválasztás a közösségi közlekedésben; párhuzamos közlekedési kínálat; logit-modell; 


\section{REFERENCES}

[1] Ivković I, Čokorilo O, Kaplanović S. The estimation of GHG emission costs in road and air transport sector: Case study of Serbia. Transport. 2018;33(1): 260-267.

[2] Farkas D, Hagymási G, Nagy B. [A helyközi közösségi közlekedés jelenlegi helyzetének ismertetése és hazai szervezésének lehetőségei]. Vezetéstudomány. 2010;5: 26-36. Hungarian.

[3] Ács B. [A távolsági autóbusz-hálózat múltja, jelene, jövője]. KTI Évkönyv. 2007; 18-26.

[4] Abramovic B, Zitricky V, Mesko P. Draft methodology to specify the railway sections capacity. LOGI-Scientific Journal on Transport and Logistics. 2017;8(1): 1-10.

[5] Abramović B. Infrastructure Access Charges. In: Marinov M. (eds) Sustainable Rail Transport. Lecture Notes in Mobility. Springer, Cham; 2018. p. 45-58.

[6] Droździel P, Rybicka I, Madleňák R, Andrusiuk A, Siłuch $\mathrm{D}$. The engine set damage assessment in the public transport vehicles. Advances in Science and Technology Research Journal. 2017;11(1): 117-127.

[7] Gašparík J, Abramović B, Zitrický V. Research on Dependences of Railway Infrastructure Capacity. Tehnički vjesnik. 2018;25(4): 1190-1195.

[8] Gasparik J, Mesko P, Zahumenska Z. Methodology for Tendering the Performances in Long Distance Rail Passenger Transport. Periodica Polytechnica Transportation Engineering. 2019;47(1): 19-24. Available from: doi:10.3311/PPtr.11192 [Accessed 14 ${ }^{\text {th }}$ March 2019].

[9] Zitrický V, Černá L, Abramović B. The proposal for the allocation of capacity for international railway transport. Procedia Engineering. 2017;192: 994-999.

[10] Kuang Z, Lian Z, Lien JW, Zheng J. Serial and parallel duopoly competition in multi-segment transportation routes. Transportation Research Part E: Logistics and Transportation Review. 2020;133: 101821.

[11] Llano C, De la Mata T, Diaz-Lanchas J, Gallego N. Transport-mode competition in intra-national trade: An empirical investigation for the Spanish case. Transportation Research Part A: Policy and Practice. 2017;95: 334-355.

[12] Van der Weijde AH, Verhoef ET, van den Berg VA. Competition in multi modal transport networks: a dynamic approach. Transportation Research Part B: Methodological. 2013;53: 31-44.

[13] Albert G, Tóth Á [A párhuzamosság, helyettesíthetőség számszerüsítése a közforgalmú közlekedésben]. Közlekedéstudományi Szemle. 2008;3: 30-35. Hungarian.

[14] Zhu F, Chen S, Lv Y, Ye P, Xiong G, Dong X. Parallel public transport system and its application in the evacuation of large-scale activities. Intelligent Transportation Systems (ITSC), $15^{\text {th }}$ International IEEE Conference;
2012. p. 102-107.

[15] Mándoki P, Lakatos A. [A magyarországi vasúti és távolsági autóbuszos személyszállítás párhuzamosságának kérdései az utazási paraméterek szempontjából]. Közlekedéstudományi Szemle. 2017;03: 63-77. Hungarian.

[16] Lakatos A, Mándoki P. [A magyarországi regionális vasúti és autóbuszos személyszállítás párhuzamosságának többszempontú vizsgálat alapján történő összehasonlítása]. XII. IFFK Conference, Budapest, Hungary; 2018. p. 371-382. Hungarian.

[17] Kövesné, Debreczeni G, Csiszár Cs. [Személyközlekedés]. Digital curriculum. 2014. Available from: http://kukg.bme.hu/wp-content/uploads/2019/02/SZK jegyzet.pdf [Accessed $1^{\text {th }}$ Aug 2018].

[18] BuisML.Logisticregression:Whencanwedowhatwethink we can do? 2016. Available from: http://www.maartenbuis.nl/wp/odds_ratio_3.1.pdf [Accessed $14^{\text {th }}$ March 2019].

[19] Hajdú L. [A logisztikus függvény és a logisztikus eloszlás]. Statisztikai szemle. 2014;1(82): 991-1011. Hungarian.

[20] Allison P. Comparing logit and probit coefficients across groups. Sociological Methods \& Research. 1999;28(1): 186-208.

[21] KTI. [Országos célforgalmi felvétel és mátrixok kidolgozása (OCF-2016)]; 2017. Hungarian.

[22] Martínez F, Aguila F, Hurtubia R. The constrained multinomial logit: A semi-compensatory choice model. Transportation Research Part B: Methodological. 2009;43(3): 365-377.

[23] Tánczos L, Török Á. [Közúti közlekedési módválasztás modellezése Budapest és Györ között]. Közlekedéstudományi Szemle. 2007;57: 220-226. Hungarian.

[24] Kosztyó Á, Török Á. [Döntésmodellezés a közúti közlekedési módválasztásban]. Marketing És Menedzsment. 2007;XLI: 48-51.

[25] Lakatos A, Mándoki P. [Felhasználói eszközválasztás vizsgálata a távolsági, párhuzamos közösségi közlekedésben]. Conference of Transport Sciences, Györ, Hungary; 2019. Hungarian.

[26] MÁV-HÉV Zrt. [Változik a H6-os, a H8-as és a H9-es HÉV menetrendje - több vonat, jobb csatlakozások]; 2017. Available from: https://www.mavcsoport.hu/ mav/valtozik-h6-os-h8-es-h9-es-hev-menetrendje-tobbvonat-jobb-csatlakozasok [Accessed 15 ${ }^{\text {th }}$ June 2017]. Hungarian.

[27] Finland. VR to close nearly 30 train stations, some routes; 2017. Available from: https://yle.fi/uutiset/osasto/news/vr_to_close_nearly_30_train_stations_some routes $/ 8307702$ [Accessed $20^{\text {th }}$ Sept 2017]. 